\title{
a proposed standard method of
}

\section{Measuring Hospital Capacity}

\author{
PAUL A. LEMBCKE, M.D., M.P.H., DAVID R. HERMANSEN, M.A., \\ and ELEANOR POLAND, Ph.D.
}

$A^{\prime}$ STANDARD method of determining bed capacity and the adequacy of space in basic departments is necessary in judging the extent to which hospital needs are being met by existing and proposed buildings.

Hospital needs and resources have traditionally been expressed in terms of beds, which by definition include facilities for both adults and children, but not bassinets for the newborn in a nursery, beds in labor rooms and in health centers, and beds used exclusively for emergency purposes. This definition is incomplete, however. Should the count represent the situation on some one day or throughout the year? Should it be the maximum number or the average? These and many related questions have been resolved by the adoption of uniform definitions required for hospital operation and finance, but others have not, especially in the field of hospital survey and planning.

Another consideration is whether the hospital beds that have been enumerated are acceptable in respect to safety and efficiency.

Dr. Lembcke is professor of preventive medicine and public health, School of Medicine and School of Public Health, University of California, Los Angeles. Mr. Hermansen is assistant professor of architecture, University of Kansas. Dr. Poland is project director, Regional Health and Hospital Study, Community Studies, Inc., Kansas City, Mo. This investigation was partially supported by a research grant from the Division of Hospital and Medical Facilities, Bureau of Medical Services, Public Health Service.
The most important points to be considered in determining the acceptability of a structure are fire hazards, structural materials, exit facilities, physical condition, location, suitability of design, and adequacy of space in the essential departments.

Generally accepted methods are now available to determine the fire-resistive properties of existing and proposed hospital buildings and structural materials, and the type, number, and location of exit facilities. The physical condition of a hospital is largely a subjective determination, and the same is true of location except where it is regulated by law.

The suitability of design has many subjective elements, such as the location of the various essential departments and the proportion of beds in one-bed, two-bed, and four-bed rooms. It also has a number of objective features, such as whether the building was originally designed as a hospital, the width of doors and corridors, and the minimum and maximum number of beds in a nursing unit. But these are not included in the method we are proposing for use in measuring hospital capacity because the suitability of design as applied to existing structures is more closely related to the concept of "replaceable" bed capacity, than it is to "unsuitable" bed capacity. By "replaceable" bed capacity we mean rooms and departments that are now included in existing bed capacity but that would be differently designed when their physical condition required replacement by new construction. In such authoritative hos- 
pital surveying and planning as that under the Federal Hospital Survey and Construction (Hill-Burton) Act, "unsuitable" beds are not counted in determining the needs for new construction.

\section{Importance of Adequate Space}

Safety. Since 1942, when 491 persons died in the Cocoanut Grove fire in Boston, most State and local governments have recognized the necessity of limiting the occupancy of a theater, restaurant, school, or other public place to the number of people who can be allowed in a given space without endangering their lives in case fire or other accidents require that the premises be vacated quickly. Enforcement requires that the maximum number of persons who can occupy such places with safety be determined by reference to standards based on the space available. This principle has not been fully recognized for hospitals, although they present the additional hazards of cross-infections, of mistakes in the distribution of medicines, and other misadventures that may be aggravated by crowding and inadequate space. Cross-infections are typified particularly by the staphylococcal diseases held responsible for many complications and deaths today.

Efficiency. Adequate space for the essential departments of the hospital is as closely related to efficiency in hospitals as it is in the operation of any other institution or service, mercantile or industrial.

Rooms for patients. Modern medical and nursing care call for sufficient space around the bed to permit many procedures to be carried out in the patient's own bed in his own room. Blood transfusion, intravenous administration of fluids and medicines, the use of indwelling catheters and tidal drainage of body fluids and excretions, administration of oxygen, and decompression of the intestine by the Wangensteen apparatus are examples. Even beds must be longer to accommodate the increasing stature of the American people!

Departments. The safety and efficiency of a hospital may be impaired if one or more departments are not in proportion to the others. This occurs most commonly when beds are added to the nursing department without adding in like proportion to the administration, pathology, radiology, pharmacy, surgery, obstetrics, emergency, dietary, laundry, housekeeping, and mechanical departments or to the facilities for employees and central storage.

Other factors. As noted earlier, space is not the only criterion of suitability, and an area or department must be judged unsuitable if it is unsafe, regardless of the adequacy of its space. However, an area that is suitable in respect to safety factors may be definitively unsuitable if it falls short of meeting minimum space requirements.

\section{General Method}

Our method of determining hospital capacity requires that all the rooms or units of space in a hospital be measured, classified as to function, and allocated to the appropriate hospital departments. The areas so determined are then compared with nationally recognized standards of space for such departments. This method presents consistent, objective criteria of the sufficiency or deficiency of each department and of the hospital as a whole. A given hospital may be found deficient in respect to the rooms for patients, the adjunct diagnostic and treatment facilities, and the administrative and service areas, or it may measure up in all respects, or, as is more common, it may meet standards for patients' rooms but not for other departments. The method is sufficiently flexible to accommodate the use of different standards as desired or as they change with advances in medical care.

\section{Definitions of Hospital Bed Capacity}

To avoid confusion it is necessary in every instance to distinguish between the three importantly different meanings of hospital bed capacity-bed complement, normal bed capacity, and potential bed capacity.

The terms "normal" and "potential" bed capacity were used by the Commission on Hospital Care in the schedules of information (1) to be gathered in determining hospital capacity, although a discussion of these terms was not included in its published reports $(\mathscr{2}, 3)$. 
Bed complement. The term "bed complement" refers to the number of beds set up and ready for use at any given time, regardless of the floor space allotted to the beds or the areas in which they are found. Bed-complement figures are often misleading because they do not indicate the normal safe and efficient working capacity of a hospital. Complement includes beds crowded into rooms intended for fewer patients and beds that have been set up on enclosed porches, in hallways, solariums, treatment rooms, and other areas not originally designed for occupancy by bed patients. Bedcomplement figures may be misleading also when, as in resort areas, a portion of the hospital is closed during the off-season.

Normal bed capacity. The evaluation of existing facilities and the design of new areas for patients must be based on the concept of normal bed capacity. The term refers to the number of hospital beds appropriate for the patients' rooms as the result of two factors in design: $(a)$ the provision of a minimum number of square feet per bed and $(b)$ the intention of the designer. The second factor governs in instances where, according to minimum space standards, the area of a room seems sufficient to accommodate a larger number of beds than that for which it was designed.

For example, a hospital room designed for occupancy by only one patient is not to be considered as a two-bed room merely because it has an area as great as the minimum prescribed for a two-bed room. A one-bed room may be relatively large because it was designed as a luxury accommodation, or more frequently the room may be intended for the isolation of a noisy alcoholic or mentally ill patient or one with a communicable disease. In such rooms the location of toilet, lavatory, and storage space and the inclusion of such features as double doors may preclude the accommodation of two beds for average patients without a dangerous or inefficient degree of crowding.

Potential bed capacity. This is a term not frequently encountered. As defined by the Commission on Hospital Care, potential bed capacity designates areas of the hospital currently used for other purposes but intended for the eventual accommodation of patients as the need for hospital beds increases. For example, student nurses might be housed for a time in a division of the hospital designed for future conversion to a nursing unit for patients.

\section{Standard Space Allocations}

The space allocations used as standards in this study were first published by Shaffer and MacDonald in 1943 (4) for hospitals built in the emergency defense program under the Lanham Act. They appeared in Modern Hospital in 1947 and 1948 in a series of articles entitled "The Functional Basis of Hospital Planning," prepared by the Hospital Facilities Section of the Public Health Service. The series was reprinted as a 110-page monograph, "Design and Construction of General Hospitals," subtitled "A Definitive Study of the Physical Aspects of the Hospital Plant in Relation to Its Function" (5).

The standards are minimum (6). In fact, a related series of articles published by the Public Health Service in 1946 suggested larger dimensions of various elements of the general hospital for new construction ( 7$)$, and some of these elements were revised upward in $1952(8)$. Many hospitals constructed under the HillBurton Hospital Survey and Construction Act exceed the suggested floor areas, for example those described in three articles in the Journal of the American Institute of Architects (9). More ample areas were recommended in a 1954 publication from another source (10), and present indications are that future revisions of the standards will call for larger areas. However, the $1947-48$ standards seem to be reasonable for judging existing structures.

\section{Standards for Hospitals of Different Sizes}

Because "Design and Construction of General Hospitals" gives figures only for hospitals of $25,50,100,150$, and 200 beds (5), it was necessary to devise some method of assessing the measured capacity of existing hospitals of intermediate sizes. The problem was complicated by the fact that no one department has a constant number of square feet per bed throughout the range from 25 to 200 beds. In attacking this problem we were well aware that in many instances the space needs of a hospital increase by multiples of functional units rather than by an increase in the size of the individual 
units-large hospitals need more toilets or janitor closets, not larger ones. In some functional units, such as waiting rooms, staff conference rooms, and medical records rooms, the space allocation increases in proportion to the number of beds in the hospital, but in others the picture is not as clear. For example, if the director of nursing service in a 50-bed hospital needs an office of 130 square feet, it does not follow that in a 100-bed hospital the same type of office needs to be twice as large, or any larger. In "Elements of the General Hospital" the office in the 50-bed hospital is designed for one person and is furnished with one executive desk, chair, and wastebasket, two straight chairs, one bookshelf, and three filing cabinets. The office in the 100-bed hospital is also for one person and has the same area and same furniture, except that it has only two filing cabinets instead of three ( $(7)$. Is there then no need to increase the size of areas such as this in proportion to the increase in normal bed capacity?
The answer is that a functional unit such as the office of the director of nursing service need not be enlarged, but the area of the whole administration department of which it is a part does need to be enlarged to accommodate the increased work of directing the nursing service. The more beds in the hospital, the more patients and nurses. The more nurses, the more time records, dossiers and registers, correspondence and conferences, each requiring a little more space. Recognition of this and similar needs is given by suggesting 2,975 square feet for the administration department of the 100bed hospital in contrast to 1,970 square feet in the 50-bed hospital (5). When the hospital increases to the 100-bed level, the office of the director of nursing service remains constant, but provision is made for the increased records and activities to be accommodated in part in a larger business office with five employees instead of three, in the larger medical records, conference, and waiting rooms, and in two types

\section{Table 1. Area distribution in net square feet per bed for departments of general hospitals}

\begin{tabular}{|c|c|c|c|c|c|}
\hline Departments or divisions & $15-37$ beds & $38-74$ beds & $75-124$ beds & $\begin{array}{c}125-174 \\
\text { beds }\end{array}$ & $\begin{array}{l}175 \text { beds } \\
\text { and over }\end{array}$ \\
\hline $\begin{array}{l}\text { Administration } \\
\text { Laboratory } \\
\text { Morgue } \\
\text { Radiology } \\
\text { X-ray therapy } \\
\text { Physical therapyy } \\
\text { Occupational therapy } \\
\text { Pharmacy } \\
\text { Nursing } \\
\text { Nursery } \\
\text { Obrgical } \\
\text { Obsterics } \\
\text { Emergency } \\
\text { Dietary } \\
\text { Eentral storage } \\
\text { Employees facilities } \\
\text { Housekeeping and linen } \\
\text { Laundry } \\
\text { Mechanical facilities } \\
\text { Circulation spaces (corridors, stairways, } \\
\text { elevators) }\end{array}$ & $\begin{array}{r}47.0 \\
6.0 \\
16.0 \\
173.0 \\
15.2 \\
43.0 \\
29.4 \\
12.8 \\
44.8 \\
25.0 \\
20.0 \\
7.4 \\
4.6 \\
29.0 \\
111.2\end{array}$ & \begin{tabular}{r|}
39.4 \\
5.6 \\
5.6 \\
11.3 \\
10.4 \\
176.1 \\
10.0 \\
39.6 \\
23.5 \\
7.4 \\
48.0 \\
23.5 \\
15.3 \\
8.6 \\
18.7 \\
20.6 \\
160.2
\end{tabular} & 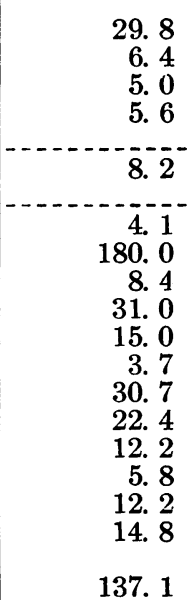 & \begin{tabular}{r}
23.8 \\
6.3 \\
3.3 \\
7.2 \\
\hdashline 6.8 \\
2.7 \\
4.0 \\
180.0 \\
8.0 \\
28.1 \\
12.7 \\
3.4 \\
25.1 \\
22.2 \\
10.6 \\
4.2 \\
11.3 \\
12.0 \\
135.2
\end{tabular} & $\begin{array}{r}23.9 \\
5.6 \\
2.5 \\
6.4 \\
8.8 \\
6.1 \\
2.5 \\
3.6 \\
180.0 \\
8.2 \\
25.2 \\
10.6 \\
3.9 \\
25.2 \\
22.0 \\
9.5 \\
3.5 \\
10.1 \\
9.8 \\
134.4\end{array}$ \\
\hline Total & 587.0 & 627.9 & 532.4 & 507.0 & 501.6 \\
\hline
\end{tabular}

Note: Areas do not include walls and partitions. Bed capacities are based on adult and child beds only. Space for bassinets is included in the nursery, but these bassinets are not counted as beds. The areas do not include outpatient department, quarters for personnel, nursing school or any other teaching areas, fuel storage, garage, or any other area not specified in the department column. For a detailed description of units within the departments by size of hospital, see reference 5 .

Source: The five columns correspond with the data summarized in reference 5 for hospitals of $25,50,100,150$, and 200 beds, respectively, with the following modifications: (a) a formula room of 255 square feet has been included in the 50-bed hospital dietary facilities as the omission of any formula room in a hospital of this size was apparently an error; (b) small errors in addition or rounding have been corrected. 
of rooms that first appear at the 100-bed levelsocial service and retiring room $(\%, 8)$.

A stepup in this element of a general hospital comes at the 200-bed level, where provision is made for two offices of 215 square feet each, one for the director and one for two assistant directors of nursing service. At this level the increased prestige of the director is acknowledged by giving her a larger office, although not too large for a supervisor of a staff of 80 to 100 nurses and auxiliary workers.

In any event, one can discern the principle that as the volume of hospital service increases a roughly proportional increase in the various departmental areas is required, although the need for more space to perform a specific function may be hidden for a time by the shifting or delegation of various components of the function to other areas.

It was primarily the hidden growth factor explained and illustrated above that influenced us to calculate the space needs of hospitals of other than the sizes in "Design and Construction of General Hospitals" by interpolation and by extrapolation beyond the upper and lower figures. The midpoints between hospitals of given sizes were used to demarcate the size classes of hospitals to which a given number of square feet per bed applied: 15-37, 38-74, 75-124, 125-174, and 175 beds and over, as shown in table 1 .

\section{Departmental Areas and Units}

The 587 square feet per bed suggested for a 25-bed hospital was assigned to hospitals of the 15-37 bed class, the 627.9 square feet for a 50bed hospital was assigned to the 38-74 bed class, the 532.4 for a 100-bed hospital to the 75-124 bed class, the 507 for a 150-bed hospital to the 125-174 bed class, and the 501.6 square feet per bed suggested for a 200-bed hospital was assigned to hospitals of 175 beds and over (5). Table 1 presents the standard net square feet per bed for each department according to hospital size. To obtain the standard area for a department in a given hospital, the square feet per bed for the size class in which the hospital falls is multiplied by the normal bed capacity.

A standard square footage per bed for some of the large units within the departments can be derived in the same manner, but for the reasons given in the subsection, Standards for Hospitals of Different Sizes, it is not often permissible to go below the departmental level in interpolating or extrapolating.

\section{Rooms for Patients}

The maximum normal bed capacity of each room for patients is calculated from the following range of square feet per number of beds in a room:

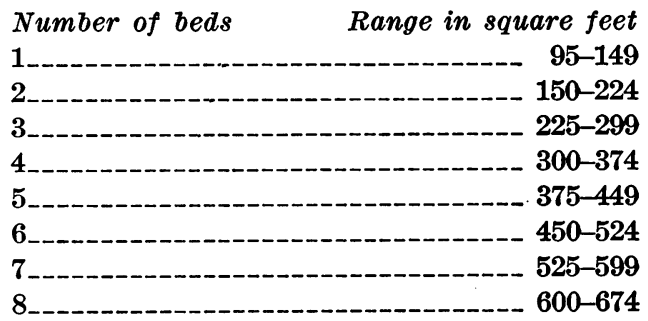

This index is based on the minimum of 100 square feet of open space for one-bed and 80 square feet per bed for multiple-bed rooms (private closets, lockers, toilets, and showers excluded) required for hospitals to be constructed under the Hill-Burton Act (11). We believe this choice of standard is justified because our purpose is to analyze and evaluate existing structures rather than to plan new construction.

In applying these standards to patients' rooms, deviations of 5 square feet per bed below the minimum are accepted because measurements made in the field are not highly exact and because of the difficulty of making allowances for columns, radiators, ducts, and similar design features. The majority of measurements, except for small areas such as closets and toilets, were made with a measuring wheel device. Dimensions were recorded at the hospital or rounded in the office to the nearest one-half foot. For example, a dimension measuring between 9 feet 9 inches and 10 feet 2 inches would be recorded as 10 feet, a tolerance of 5 percent. The interval between 11 feet 3 inches and 11 feet 8 inches would be represented by 11 feet 6 inches, and so on.

\section{Application of Method}

The method described in this article compares the space for beds and supporting hospital de- 


\section{Hospital X, Second Floor Plan}

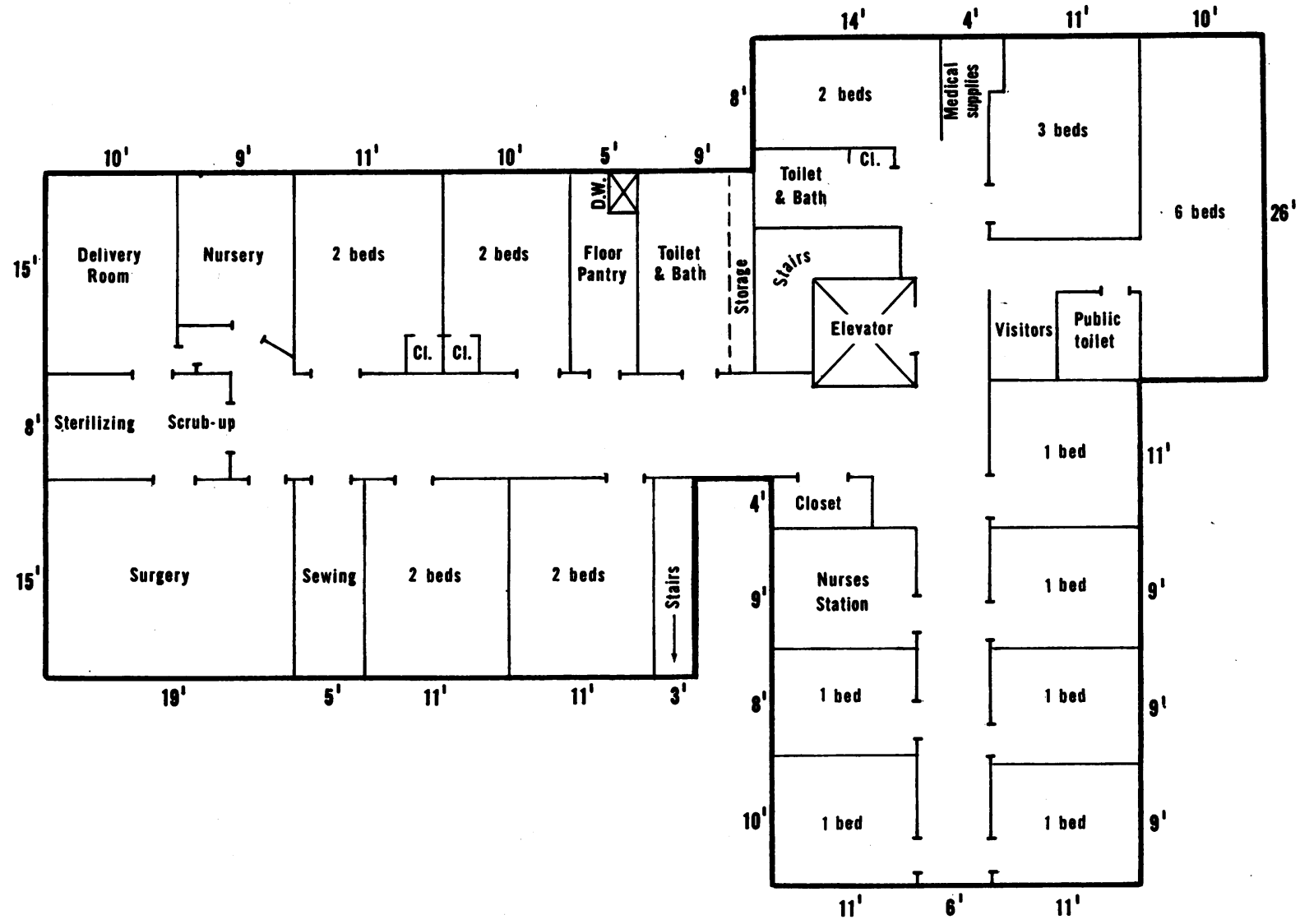

partments with minimum standards for hospitals of similar size. The following is a comparison of two actual hospitals.

\section{Hospital $X$}

Hospital $\mathrm{X}$ occupies a two-story building, with partial basement, that was designed as a hospital. The exact date of the original building is unknown. One section was remodeled in 1936 and some changes were made in other sections in 1946 and 1951. The general layout of the hospital is indicated by the sketch of the second floor (see chart). Although the structure did not have a fire-resistive rating of 1 hour or more, a sprinkler system complying with State licensing regulations was installed and the building was considered to be suitable.

The 1958 revision of the State Plan for the Construction of Hospital and Medical Facilities listed hospital $\mathrm{X}$ as having 40 acceptable beds. An average daily census of 32 was reported for the previous year, which would re- quire 49 beds for high-level and 55 beds for low-level occupancy, according to the Commission on Hospital Care (2). On the day of our survey, 45 beds were set up. There were 41 patients in the hospital, nurseries excluded.

Normal bed capacity. The area in each room was measured and its maximum capacity was calculated according to our index (p. 678). The figures in table 2 show that although hospital $\mathrm{X}$ had a bed complement of 45 on the day of the survey, the normal bed capacity of its rooms for patients totaled only 32. Instead of being set up with 6 one-bed rooms, 13 two-bed rooms, 2 three-bed rooms, 1 six-bed room, and 1 bed in a hall, hospital $\mathrm{X}$ should have had no more than 11 one-bed rooms, 9 two-bed rooms, and 1 three-bed room.

Departmental areas. The adequacy of space in other departments essential to the care of inpatients was determined by comparison with the standard space allocations for hospitals of 32 beds. Each functional unit was measured, 
Table 2. Normal bed capacity of hospital $X$ compared with bed complement at time of survey

\begin{tabular}{|c|c|c|}
\hline $\begin{array}{l}\text { Area of rooms } \\
\text { (square feet) }\end{array}$ & $\begin{array}{c}\text { Bed } \\
\text { comple- } \\
\text { ment }\end{array}$ & $\begin{array}{c}\text { Normal } \\
\text { bed } \\
\text { capacity }\end{array}$ \\
\hline One-bed rooms & & \\
\hline 9 & 1 & 1 \\
\hline 99 & 1 & 1 \\
\hline $99 \ldots$ & $\begin{array}{l}1 \\
1\end{array}$ & $\begin{array}{l}1 \\
1\end{array}$ \\
\hline Two-bed rooms & & \\
\hline 112 & $\begin{array}{l}2 \\
2\end{array}$ & $\begin{array}{l}1 \\
1\end{array}$ \\
\hline 140 & 2 & 1 \\
\hline $140 \ldots \ldots$ & 2 & 1 \\
\hline$\cdots$ & $\begin{array}{l}2 \\
2\end{array}$ & $\begin{array}{l}1 \\
2\end{array}$ \\
\hline (n) & 2 & 2 \\
\hline $\begin{array}{l} \\
-1\end{array}$ & $\begin{array}{l}2 \\
2\end{array}$ & 2 \\
\hline 165 & $\begin{array}{l}2 \\
2\end{array}$ & $\stackrel{2}{2}$ \\
\hline 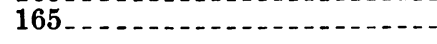 & 2 & 2 \\
\hline Three-or-more-bed rooms & & \\
\hline $\begin{array}{l}165 \\
195_{-}\end{array}$ & $\begin{array}{l}3 \\
3\end{array}$ & $\begin{array}{l}2 \\
2\end{array}$ \\
\hline . & 6 & \\
\hline Hall-be & 1 & $\mathbf{0}$ \\
\hline Total & 45 & 32 \\
\hline
\end{tabular}

and the dimensions and the use being made of each room at the time of the survey were recorded on floor plans of the hospital (see chart). The data were processed in our office by assigning each room to the appropriate department and entering the dimensions and square feet on forms that grouped the rooms by departments and indicated whether the function was required for a hospital of this size.

The comparison of the areas in each department of hospital $\mathbf{X}$ with the corresponding standards for a 32-bed hospital shows a measured deficit of 9,018 square feet. The departments that were most deficient were surgery, with about one-fourth of the space it should have in a 32-bed hospital, obstetrics with 150 instead of 941 square feet, and dietary with 445 instead of 1,434 square feet. Administration had only 575 instead of 1,504 square feet (table 3).
The departmental deficiencies can be seen more clearly if considered in the detail suggested by table 4. The surgical department has insufficient space for central sterilizing and supply, and no space at all for substerilizing room, unsterile supplies, cleanup room, doctors' locker room, janitor's closet, and anesthesia storage. The obstetrics department has inadequate space in the delivery room and none for labor room, substerilizing, cleanup or utility room, and janitor's closet. There is no scrubup room for the obstetrics department alone. The surgical scrubup room serves both departments.

Although departmental deficiencies appear most clearly in administration, surgery, obstetrics, and the service departments, it is important to note that the nursing department lacks 1,560 square feet of the space needed to support the normal capacity of 32 beds. From the floor plan it can be seen that most of the rooms for patients have no private or semi-

Table 3. Departmental areas in hospital $X$ compared with minimum standards for a normal capacity of 32 beds, in square feet

\begin{tabular}{|c|c|c|c|}
\hline \multirow{2}{*}{ Departments or divisions } & \multicolumn{2}{|c|}{$\begin{array}{l}\text { Standard area } \\
\text { for } 32 \text { beds }\end{array}$} & \multirow{2}{*}{$\begin{array}{l}\text { Actual } \\
\text { areas } \\
\text { in hos- } \\
\text { pital X }\end{array}$} \\
\hline & $\begin{array}{c}\text { Per } \\
\text { bed }^{2}\end{array}$ & $\begin{array}{c}\text { Per } \\
\text { depart- } \\
\text { ment }^{3}\end{array}$ & \\
\hline $\begin{array}{l}\text { Administration } \\
\text { Laboratory } \\
\text { Radiology } \\
\text { Pharmacy } \\
\text { Nursing } \\
\text { Nursery } \\
\text { Surgical } \\
\text { Obstetrics } \\
\text { Emergency } \\
\text { Dietary } \\
\text { Central storage } \\
\text { Employees facilities } \\
\text { Housekeeping and linen } \\
\text { Mechanical facilities } \\
\text { Circulation spaces (corri- } \\
\text { dors, stairways, eleva- } \\
\text { tors) }\end{array}$ & $\begin{array}{r}47.0 \\
6.0 \\
16.0 \\
2.0 \\
173.6 \\
15.2 \\
43.0 \\
29.4 \\
12.8 \\
44.8 \\
25.0 \\
20.0 \\
7.4 \\
29.0\end{array}$ & $\begin{array}{r}1,504 \\
192 \\
512 \\
64 \\
5,555 \\
486 \\
1,376 \\
941 \\
410 \\
1,434 \\
800 \\
640 \\
237 \\
928\end{array}$ & $\begin{array}{r}575 \\
180 \\
435 \\
100 \\
3,995 \\
100 \\
370 \\
150 \\
0 \\
445 \\
405\end{array}$ \\
\hline Total $4 \ldots \ldots$ & 582.4 & 18,637 & 9,655 \\
\hline
\end{tabular}

145 beds on survey day.

2 Standard for hospitals of 15-37 normal bed capacity.

3 Product of standard space allocations per bed and normal bed capacity.

4 Excludes standard space for laundry because there is no laundry in this hospital. 
Table 4. Space allocations in surgical and obstetrics departments of hospital $X_{1}^{1}$ compared with space suggested for such departments in a 25-bed hospital, ${ }^{2}$ in square feet

\begin{tabular}{|c|c|c|}
\hline Departments or divisions & $\begin{array}{c}\text { Actual } \\
\text { space in } \\
\text { hospital } \\
\text { X }\end{array}$ & $\begin{array}{c}\text { Minimum } \\
\text { standard } \\
\text { for 25-bed } \\
\text { hospital }\end{array}$ \\
\hline Surgical department & & \\
\hline $\begin{array}{l}\text { Major operating rooms } \\
\text { Scrubup facilities } \\
\text { Substerilizing rooms } \\
\text { Central sterilizing and supply } \\
\text { Unsterile supply room } \\
\text { Cleanup room } \\
\text { Janitor's closet } \\
\text { Doctors locker room } \\
\text { Anesthesia storage }\end{array}$ & $\begin{array}{r}285 \\
30 \\
0 \\
55 \\
0 \\
0 \\
0 \\
0 \\
0\end{array}$ & $\begin{array}{r}320 \\
30 \\
50 \\
255 \\
75 \\
90 \\
20 \\
185 \\
50\end{array}$ \\
\hline Total & 370 & 1,075 \\
\hline $\begin{array}{l}\text { Obstetrics department } \\
\text { Delivery room } \\
\text { Labor room } \\
\text { Scrubup facilities } \\
\text { Substerilizing } \\
\text { Cleanup room } \\
\text { Janitor's closet. }\end{array}$ & 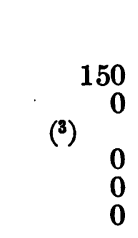 & $\begin{array}{r}290 \\
255 \\
30 \\
50 \\
90 \\
20\end{array}$ \\
\hline Total_- & 150 & 735 \\
\hline
\end{tabular}

${ }^{1} 45$ beds on survey day.

2 Reference 5.

3 The surgical scrubup room is used.

private toilets and very few have closets. There are no subutility rooms, nurses' toilets, or janitors' closets anywhere in the hospital. There is only one nurses' station for two floors and basement. The floor pantries are substandard in size, and the storage areas for linen and other supplies that should be on hand in the nursing unit are not only too small but are all on the second floor, far from the patients' rooms on the first floor and in the basement.

\section{Hospital $A$}

This one-story and basement fire-resistive structure, built in 1956, was designed to accommodate 42 patients in 2 one-bed, 16 twobed, and 2 four-bed rooms. The one-bed rooms each contained 135 square feet. The multiplebed rooms each contained 80 or more square feet per bed.

Normal bed capacity. According to our method the normal bed capacity was 40 . There were five beds in one room of 395 square feet, sufficient open space to permit classification as a five-bed room, according to our index, but it was clearly designed for four beds, having no bay for a fifth bed and being identical with another room in which only four beds were set up. As shown in table 5, the space allocated to obstetrics was notably deficient and there was no physical therapy department. The nursing department was deficient in having only two

Table 5. Departmental areas in hospital A
compared with minimum standards for a nor-
mal capacity of 40 beds, in square feet

\begin{tabular}{|c|c|c|c|}
\hline \multirow{2}{*}{ Departments or divisions } & \multicolumn{2}{|c|}{$\begin{array}{l}\text { Standard mini- } \\
\text { mum area for } \\
40 \text { beds }\end{array}$} & \multirow{2}{*}{$\begin{array}{l}\text { Actual } \\
\text { areas in } \\
\text { hospital } \\
A^{1}\end{array}$} \\
\hline & $\underset{\text { bed }^{2}}{\text { Per }}$ & $\begin{array}{l}\text { Per de- } \\
\text { part- } \\
\text { ment } 3\end{array}$ & \\
\hline $\begin{array}{l}\text { Administration } \\
\text { Laboratory } \\
\text { Radiology } \\
\text { Physical therapy } \\
\text { Pharmacy } \\
\text { Nursing } \\
\text { Nursery } \\
\text { Surgical } \\
\text { Obstetrics } \\
\text { Emergency } \\
\text { Dietary } \\
\text { Central storage } \\
\text { Employees facilities. } \\
\text { Housekeeping and linen } \\
\text { Mechanical facilities } \\
\text { Circulation spaces (corri- } \\
\text { dors, stairways, eleva- } \\
\text { tors) }\end{array}$ & $\begin{array}{r}\text { 39. } 4 \\
5.6 \\
11.3 \\
10.4 \\
4.1 \\
176.1 \\
10.0 \\
39.6 \\
23.5 \\
7.4 \\
48.0 \\
23.5 \\
15.3 \\
8.6 \\
20.6 \\
160.2\end{array}$ & $\begin{array}{r}1,576 \\
224 \\
452 \\
416 \\
164 \\
7,044 \\
400 \\
1,584 \\
940 \\
296 \\
1,920 \\
940 \\
612 \\
344 \\
824 \\
\\
6,408\end{array}$ & $\begin{array}{r}2,085 \\
265 \\
500 \\
155 \\
5,745 \\
560 \\
1,350 \\
585 \\
500 \\
1,785 \\
1,945 \\
695 \\
310 \\
1,835\end{array}$ \\
\hline $\begin{array}{l}\text { Total departmental } \\
\text { area }\end{array}$ & 603.6 & 24,144 & 23,455 \\
\hline & \multicolumn{3}{|c|}{ Potential capacity } \\
\hline $\begin{array}{l}\text { Nursing department stor- } \\
\text { age }{ }^{5} \\
\text { Other }{ }^{6}\end{array}$ & & & $\begin{array}{r}190 \\
11,620\end{array}$ \\
\hline Total potential area_ & - - - & $\ldots$ & 11,810 \\
\hline Grand total & 603.6 & 24,144 & 35,265 \\
\hline
\end{tabular}

142 beds on survey day.

2 Standard for hospitals of 38-74 normal bed capacity.

3 Product of standard space allocation per bed and normal bed capacity.

4 Excluding space for laundry since laundry is not done in institution.

5 Furniture storage, suitable for future addition to nursing department area.

- Unoccupied space in basement suitable for future additions to adjunct diagnostic and treatment facilities or service departments. 
one-bed rooms. The other deficiencies, in pharmacy, surgery, dietary, and housekeeping were minor.

Potential bed capacity. As shown in table 5, a room of 190 square feet used to store furniture had been designed for patients and provided a potential capacity of two beds. Also, 11,810 square feet of undeveloped space in the basement was adequate to make up the total deficiency of 2,473 square feet in physical therapy, nursing, surgery, obstetrics, dietary, and housekeeping, if and when necessary, and in addition it provided a potential capacity of 7,879 square feet, enough to provide supporting departments for an 18-bed addition to the nursing department.

\section{Findings for Two Hospitals}

One of the two actual hospitals used to illustrate the method had 45 beds set up on the survey day, but was found to have a normal capacity of only 32 beds and a measured deficit of 9,018 square feet in the departments essential for a 32-bed hospital.

A more modern hospital with 42 beds set up on the survey day was found to have a normal capacity of 40 beds and a potential capacity of 2 additional beds. It had sufficient unassigned space to compensate for existing deficiencies in the departments, and undeveloped space sufficient to support an 18-bed addition to the nursing department if and when it should become necessary.

\section{Surplus Space}

Surplus space in a department or a hospital is not necessarily an extravagance. For small hospitals especially it has been recommended that new hospital construction provide basic facilities for future expansion of 50 percent or more. ". . . growth is to be expected and it should be planned for. It is good policy to install in a 50-bed hospital, for instance, service facilities large enough to care for 100 patients and to draw plans paving the way specifically for expansion to that capacity. Then when demand has reached the point where expansion is justified, patients' rooms can be added at minimum expense and with minimum dislocation of existing services" (12).

\section{Conclusions}

As a result of our studies, we strongly recommend that existing hospital facilities be resurveyed on the basis of the criteria outlined below, to determine whether they have sufficient space, properly distributed, to meet the functional demands of modern hospital care and to guarantee a reasonable measure of safety for the patient.

1. Each division, wing, or building that is unsafe or unsuitable for its purpose because of fire hazards, physical deterioration, and dangerous structural features or materials should be classified as "unsuitable." Thenceforth, only areas that are suitable should figure in the calculation of normal bed capacity and space utilization in the basic departments.

2. The rooms for patients in the nursing department should be measured and classified as described in this article to determine the "normal bed capacity." This figure should supplant the current usage of "bed capacity" that is usually based rather loosely on sources no more objective or authoritative than an unsupported statement from the hospital, or inspection without measurement.

3. The other rooms in the nursing department and the areas of all other basic hospital departments should be measured, and the standard areas required by the normal bed capacity should be calculated as described in this article.

4. The deficiency in each department should be calculated by subtracting the actual from the minimum standard area. Because this method deals with minimum figures, only deficits are counted. Surpluses should not be counted, with the single exception of potential bed capacity as defined early in this article.

This index of normal bed capacity and departmental space needs provides a quantitative measure of the adequacy of the individual hospital. It also constitutes an important step toward a complete and objective definition of hospital obsolescence, which is essential to determining the extent to which the hospital needs of a region (or a State or a nation) are met by existing and proposed hospital buildings. The hospital with deficits in essential departments can be regarded as obsolescent in that it cannot meet functional demands for modern hospital care. 


\section{REFERENCES}

(1) New York State Postwar Public Works Planning Commission, Joint Hospital Board, in cooperation with the Commission on Hospital Care: Hospital schedules of information. Schedule C. Physical plant. Albany, N.Y., 1946, 22 pp.

(2) Commission on Hospital Care: Hospital care in the United States. New York, Commonwealth Fund, 1947, 631 pp.

(3) Michigan Hospital Survey: Hospital resources and needs. Battle Creek, Mich., W. K. Kellogg Foundation, 1946, 172 pp.

(4) Shaffer, M., and MacDonald, N. F.: Planning suggestions and demonstration plans for acute general hospitals. Hospitals 17: 35-68, July 1943.

(5) U.S. Public Health Service : Design and construction of general hospitals. A definitive study of the physical aspects of the hospital plant in relation to its function. Chicago, Modern Hospital Publishing Co. [undated], 110 pp.

(6) Abbe, L. M., and Baney, A. M.: The Nation's health facilities, ten years of the Hill-Burton hospital and medical facilities program, 1946-
1956. PHS Pub. No. 616. Washington, D.C., U.S. Government Printing Office, 1958, 181 pp.

(7) U.S. Public Health Service: Elements of the general hospital. Arch. Record 99: 73-90, June 1946; 100: 76-90, July 1946. Also Hospitals 20: 53-98, May 1946.

(8) U.S. Public Health Service: Elements of the general hospital. Revised edition. Hospitals 26 79-132, April 1952.

(9) American Institute of Architects, Committee on Hospitals and Health: Hospital departmental area studies. J. Am. Inst. Architects 28 : 43-50, 215-222, 271-274, May, July, August 1957.

(10) Commission on Designing, Constructing, and Equipping of Public Hospitals in Ontario: A guide to hospital building in Ontario. Toronto, 1954, 307 pp.

(11) U. S. Public Health Service : Public Health Service regulations-Part 53, pertaining to the Hospital Survey and Construction Act as amended, revised January 23, 1958.

(12) Southmayd, H. J., and Smith, G.: Small community hospitals. Cambridge, Harvard University Press for the Commonwealth Fund, 1952, p. 108.

\section{Methylchloride Intoxication}

One death and two serious illnesses occurred recently in a small Kentucky plant fabricating Styrofoam parts, used primarily for insulation of refrigerators. The Occupational Health Branch, Public Health Service, the Kentucky State Department of Health, and the company which produces the Styrofoam cooperated in an investigation.

Symptoms were those of central nervous system damage. The man who died had worked on various machines fabricating Styrofoam parts for more than 2 years. A few weeks prior to his death, he developed what appeared to be a slight cold, followed a few days later by dizziness. The two other employees who became ill also showed signs of dizziness, accompanied by a staggering gait.

Methylchloride is used as a foaming agent in the production of Styrofoam. The material contains many tiny unconnected cells filled with the gas which is released when the Styrofoam is cut or sawed. In the Kentucky incident, poor ventilation during prolonged cold spells led to the accumulation of dangerous amounts of methylchloride in the work environment. The plant agreed to remain closed until adequate ventilation equipment could be installed. 